\title{
VASORELAXANT EFFECTS OF GLIBENCLAMIDE ON RAT THORACIC AORTA
}

\section{SIÇAN TORASİK AORTASINDA GLİBENKLAMIDIN VAZORELAKSAN ETKİLERİ}

\section{Elif ERTUNA*o, Mukadder YASA}

Ege University, Faculty of Pharmacy, Department of Pharmacology, 35100, Bornova-İzmir, TURKEY

\begin{abstract}
The purpose of this study was to investigate the effect of glibenclamide, a selective ATP-sensitive $K^{+}$ $\left(K_{A T P}\right)$ channel blocker, on agonist-induced contractions in isolated rat aortic rings. The possible involvement of endothelium in glibenclamide-induced response was also investigated. The concentrationresponse curves of prostaglandin $F_{2 \alpha}\left(P G F_{2 \alpha} ; 0.1 n M-30 \mu M\right)$, serotonin (5-hydroxytryptamine, 5-HT; $1 \mathrm{nM-}$ $30 \mu M)$ and phenylephrine $(1 \mathrm{nM}-30 \mu \mathrm{M})$ were obtained in the absence or presence of glibenclamide (1, 3 or $10 \mu \mathrm{M})$. Maximum agonist-induced contractions in the presence of glibenclamide 1,3 and $10 \mu M$ were decreased by $30 \pm 5,64 \pm 3$ and $86 \pm 2$ percent for $P G F_{2 \alpha}$ and $41 \pm 11,50 \pm 11$ and $65 \pm 5$ percent for 5-HT respectively. Phenylephrine-induced contractions remained unaltered by glibenclamide $10 \mu M$. The inhibitory effect of glibenclamide $(10 \mu M)$ on $P G F_{2 \alpha^{-}}$or 5-HT-induced contractions were attenuated upon $N^{\omega}$-nitro-L-arginin (L-NNA; $\left.100 \mu M\right)$ plus indomethacin $(10 \mu M)$ incubation. The inhibitory effect of glibenclamide on $\mathrm{PGF}_{2 \alpha}$-induced contractions was also assessed in endothelium-denuded arteries and the inhibitory effect of glibenclamide was greater in endothelium-denuded arteries than in endothelium-intact arteries pretreated with L-NNA plus indomethacin (64 $44 \%$ versus $46 \pm 10 \%$, respectively). These results suggest that glibenclamide could act through multiple sites in either endothelium or the underlying arterial smooth muscle and thus serve as a non-selective muscle relaxant at high concentration.
\end{abstract}

Key Words: glibenclamide, prostaglandin $F_{2 \infty}$ serotonin, endothelium, rat aorta 


\section{ÖZET}

Bu çalışmanin amacı ATP'ye duyarlı $K^{+}\left(K_{A T P}\right)$ kanal blokörü olan glibenklamidin agonistlerin oluşturduğu kasilmalar üzerindeki etkisini araştırmaktır. Glibenklamidin oluşturduğu cevap üzerinde endotelyumun olası katkısı da araşttrılmuşstr. Prostaglandin $F_{2 \alpha}\left(P G F_{2 \alpha} ; 0.1 n M-30 \mu M\right)$, serotonin (5hidroksitriptamin, 5-HT; $1 \mathrm{nM}-30 \mu \mathrm{M})$ ve fenilefrin (1 $n M-30 \mu \mathrm{M})$ konsantrasyon-yantt eğrileri glibenklamid (1, 3 veya $10 \mu \mathrm{M})$ varliğında veya yokluğunda alınmıştır. 1,3 ve $10 \mu \mathrm{M}$ glibenklamid varlığında maksimum

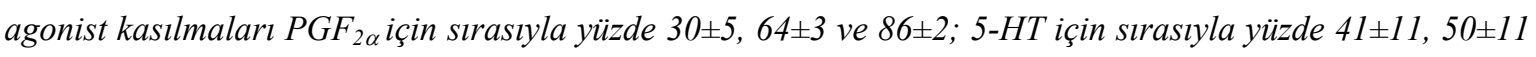
ve $65 \pm 5$ azalmıştır. $10 \mu \mathrm{M}$ glibenklamid varlığında fenilefrin kasılmalarında bir değişiklik olmamıştır. Glibenklamidin $(10 \mu M) P G F_{2 \alpha}$ veya 5-HT kasılmalart üzerindeki inhibitör etkisi $N^{\omega}{ }^{\omega}$-nitro-L-arjinin (L-NNA; $100 \mu M)$ ve indometazin $(10 \mu M)$ ile inkübasyon sonucunda azalmuştır. Glibenklamidin PGF $F_{2 \alpha}$ kasılmaları üzerindeki inhibitör etkisi endoteli kazınmış damarlarda da incelenmiş ve glibenklamidin kasılma yanıtları üzerindeki inhibitör etkisinin endoteli sağlam, L-NNA ve indometazin ile işlem görmüs damarlarla

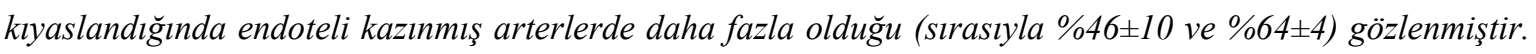
Bu sonuçlar, glibenklamidin endotelyum veya damar düz kasında birçok yerde etkisinin olabileceğini ve böylece yüksek konsantrasyonda uygulandı̆̆ında non-selektif kas gevşetici etki oluşturabileceğini göstermektedir.

Anahtar kelimeler: glibenklamid, prostaglandin $F_{2 \omega}$ serotonin, endotel, sıçan aortası

* Corresponding author, ${ }^{\circ}$ M.Sc. Thesis

\section{INTRODUCTION}

$\mathrm{K}_{\mathrm{ATP}}$ channels play an important role in control mechanisms of insuline secretion from pancreatic $\beta$-cells, prevention of brain from ischemia, modulation of transmitter release in nervous system and regulation of vascular smooth muscle tonus $(1,2,3)$. Glibenclamide, an oral hypoglycemic sulfonylurea, is a potent inhibitor of $\mathrm{K}_{\mathrm{ATP}}$ channels and of the effects of $\mathrm{K}^{+}$channels activators (4). On the other hand, it was reported that glibenclamide at high concentrations relaxed the vascular smooth muscle contracted by a thromboxane $\mathrm{A}_{2}$-mimetic, U46619 in dog coronary artery (5) and bovine coronary artery and rabbit aorta (6) or by $\mathrm{PGF}_{2 \alpha}$ in rabbit (7) and canine arteries (8) but not by other constrictors such as noradrenaline, 5-HT, phenylephrine, $\mathrm{KCl}$ or endothelin-1 $(5,6,9,10)$. An interspecies difference in the inhibitory effect of glibenclamide on muscle tension was also reported, for instance, glibenclamide failed to affect the U46619-induced contractions in human subcutaneous arteries (11). The mechanism of action of vasorelaxant effect of glibenclamide is still unknown. We hypothesise that glibenclamide at high concentrations might act as a non-selective muscle relaxant and its effects might involve endothelium derived factors. 
Therefore we first investigated whether or not glibenclamide caused an inhibitory effect on PGF $_{2 \alpha}$ contractions in rat isolated aorta and subsequently we aimed to investigate the effect of glibenclamide on contractions induced by non-prostanoid vasoconstrictors. The present study also aimed to examine the possible involvement of endothelium in glibenclamide-induced response in rat isolated aorta.

\section{MATERIALS AND METHODS}

The animal experiments were carried out in accordance with guidelines described by the Ethics Committee of the Faculty of Pharmacy, Ege University.

Male Swiss Albino rats weighing 250-300 g, were used. Rats were exanguinated after ether anesthesia. The thoracic aorta was quickly removed, cleaned of adhering fat and connective tissue. Ring segments $(3 \mathrm{~mm}$ ) were mounted in $25 \mathrm{ml}$ organs baths filled with physiological salt solution (Krebs). The Krebs solution had the following composition (in mmol/L): $\mathrm{NaCl}: 119 ; \mathrm{KCl}: 4.7$; $\mathrm{NaHCO}_{3}: 25$; Glucose: $10 ; \mathrm{CaCl}_{2}: 2.43 ; \mathrm{MgSO}_{4}: 2.4 ; \mathrm{KH}_{2} \mathrm{PO}_{4}: 1.2$. The bath solution was constantly gassed with a mixture of $95 \% \mathrm{O}_{2}$ and $5 \% \mathrm{CO}_{2}$. The tissues were allowed to equilibrate for $1 \mathrm{hr}$ under $2.5 \mathrm{~g}$ resting tension. The Krebs solution was changed at $15 \mathrm{~min}$ intervals. The contractile response (isometric tension, in g) was measured by a force transducer (Grass Instrument, Model FT03) and coupled to a data acquisition system (Polywin 95 1.0, Commat, Ankara, Turkey). In some experiments, aortic rings were pretreated with a combination of L-NNA and indomethacin or the endothelial layer was mechanically removed. The absence of functional endothelium was assessed by the lack of acetylcholine $(1 \mu \mathrm{M})$ relaxations. To avoid exposure to multiple agents or repetetive concentrations of glibenclamide, different aortic rings were used for all agents and glibenclamide concentrations.

To evaluate the effects of glibenclamide on the contractions of aortic rings, experiments were performed using rings with intact endothelium. After the equilibration period in Krebs solution, concentration-response curves to $\mathrm{PGF}_{2 \alpha}(0.1 \mathrm{nM}-30 \mu \mathrm{M})$, 5-HT $(1 \mathrm{nM}-30 \mu \mathrm{M})$ and phenylephrine $(1 \mathrm{nM}-30 \mu \mathrm{M})$ were performed to serve as control. Following 45 min washout period, glibenclamide $(1,3$ or $10 \mu \mathrm{M})$ was added to the bath and, after $15 \mathrm{~min}$, the same concentration-response curves were repeated in the presence of glibenclamide. Maximum agonistinduced contractions before and after incubation with glibenclamide were used to calculate the inhibitory effect of glibenclamide and expressed as inhibitory effect $\%$.

In experiments testing possible roles of endothelium-derived vasoactive factors, aortic rings were first exposed to L-NNA $(100 \mu \mathrm{M})$, a nitric oxide synthase inhibitor and indomethacin $(10$ 
$\mu \mathrm{M}$ ), an inhibitor of endothelial prostacyclin formation, for $30 \mathrm{~min}$. before they were contracted with $\mathrm{PGF}_{2 \alpha}, 5-\mathrm{HT}$ or phenylephrine cumulatively. In some arterial rings, the endothelial layer was mechanically removed by gently rubbing the luminal surface of the artery with forceps.

All concentrations are expressed as final molar concentrations in organ bath. Concentrationresponse curves were made by cumulative addition of a small volume of drug solutions (constrictors $100 \mu \mathrm{l}$, acetylcholine $50 \mu \mathrm{l}$ and glibenclamide $25 \mu \mathrm{l})$ in the experimental chamber $(25$ $\mathrm{ml}$ ). All solutions were freshly prepared from appropriate stock solutions. Stock solutions were made in water except for glibenclamide, dissolved in DMSO. DMSO at $0.1 \%(\mathrm{v} / \mathrm{v})$ did not affect the sustained contraction induced by $\mathrm{PGF}_{2 \alpha}, 5-\mathrm{HT}$ or phenylephrine (data not shown). Glibenclamide was kindly supplied by Nobel Pharmaceutical Industries (Istanbul, Turkey).

Data were presented as mean \pm standart error of the mean (S.E.M.) of $n$ experiments. $n$ represents the number of animals. A level of probability less than 0.05 obtained from Wilcoxon matched-pairs signed rank test or Mann-Whitney U-test was regarded as significant.

\section{RESULTS AND DISCUSSION}

Influence of glibenclamide on contractions induced by $\mathrm{PGF}_{2 \infty}$ 5-HT and phenylephrineIn the first series of experiments we investigated the contractile effects of increasing concentrations of $\operatorname{PGF}_{2 \alpha}(0.1 \mathrm{nM}-30 \mu \mathrm{M}, \mathrm{n}=6), 5-\mathrm{HT}(1 \mathrm{nM}-10 \mu \mathrm{M}, \mathrm{n}=5)$ and phenylephrine (1 nM-30 $\left.\mu \mathrm{M}, \mathrm{n}=3\right)$ on control aortic rings and on rings incubated with glibenclamide 1,3 or $10 \mu \mathrm{M}$. Pretreatment with glibenclamide $(10 \mu \mathrm{M})$ for $15 \mathrm{~min}$ had no effect on basal tension. However, the glibenclamide pretreatment caused significant rightward shifts of the concentration-response curves of $\mathrm{PGF}_{2 \alpha}$. Maximum $\mathrm{PGF}_{2 \alpha}$-induced contractions were decreased with 1,3 and $10 \mu \mathrm{M}$ glibenclamide, by $30 \pm 5,64 \pm 3$ and $86 \pm 2$ percent respectively (Figure 1A, B and C). Inhibitory effect of glibenclamide was concentration-dependent. 

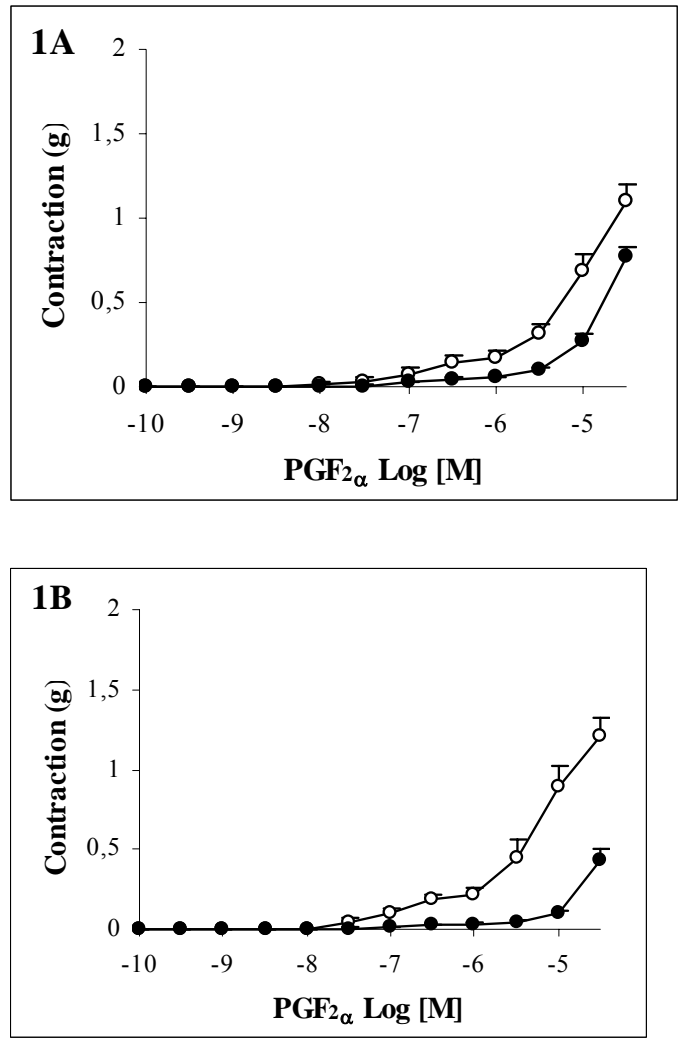

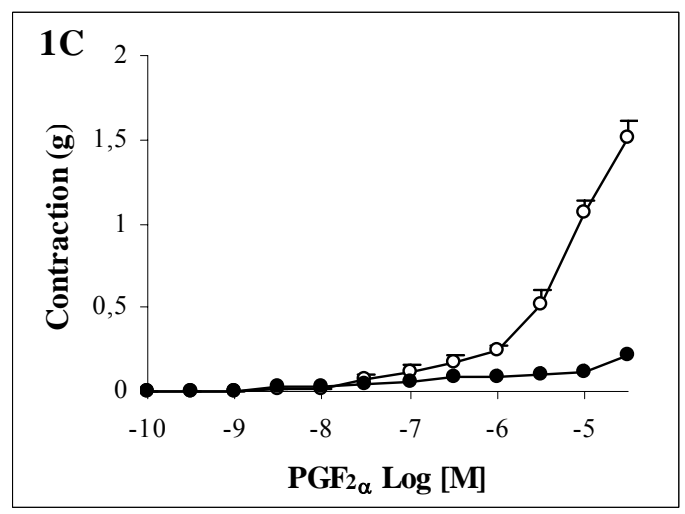

Figure 1: Concentration-response curves to $\mathrm{PGF}_{2 \alpha}$ in rat aorta. Curves were obtained in the absence $(\circ)$ and presence of glibenclamide $(\bullet)$ $1 \mu \mathrm{M}(\mathbf{A}), 3 \mu \mathrm{M}(\mathbf{B})$ and $10 \mu \mathrm{M}(\mathbf{C})$. Values are mean \pm S.E.M., $(n=6),{ }^{*} p<0.05$, Wilcoxon matched-pairs signed rank test

Further experiments were performed for non-prostanoid vasoconstrictors; 5-HT and phenylephrine. Glibenclamide caused significant inhibitory effect on 5-HT-induced contractions. Maximum agonist-induced contractions of 5-HT were decreased with 1,3 and $10 \mu \mathrm{M}$ glibenclamide, by $41 \pm 11,50 \pm 11$ and $65 \pm 5$ percent respectively (Figure 2A, B and C). Inhibitory effect of glibenclamide on 5-HT contractions was concentration dependent.

The contractions induced by phenylephrine was not significantly inhibited in the presence of $10 \mu \mathrm{M}$ glibenclamide (data not shown).

Effects of glibenclamide on vascular tone: dependence on endothelium- To preclude the possible role of endothelium in the inhibitory effect of glibenclamide, the tests were conducted in endothelium-denuded preparations. The results shown in Figure 3 indicate that the inhibitory influence of glibenclamide $(10 \mu \mathrm{M})$ on $\mathrm{PGF}_{2 \alpha}$-induced contractions is also prominent in absence of endothelium. Removal of the functional endothelium partially attenuated the inhibitory effect of glibenclamide. 

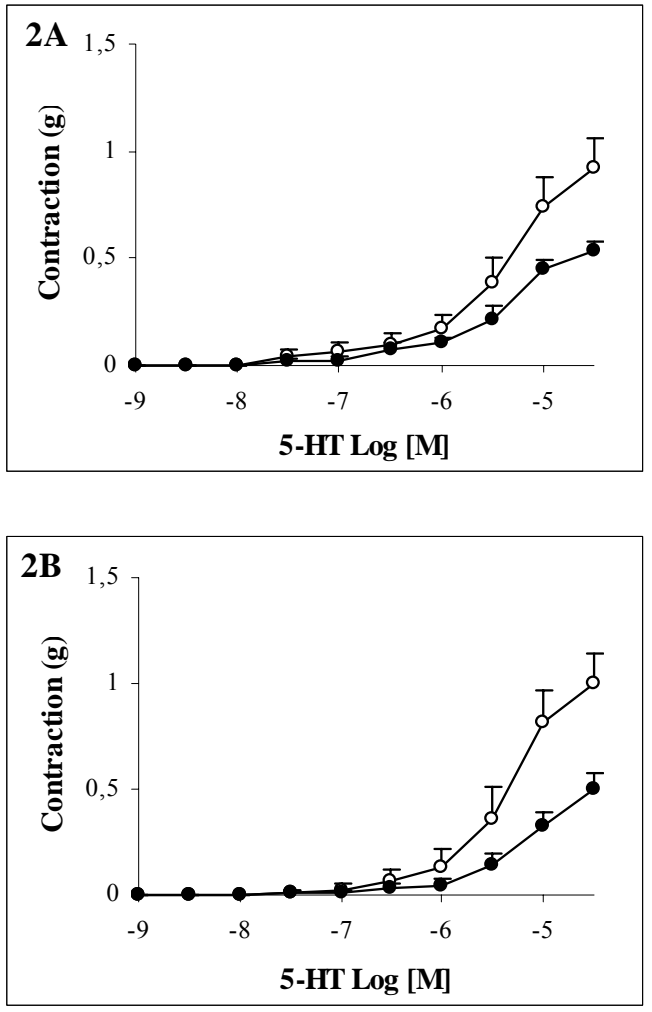

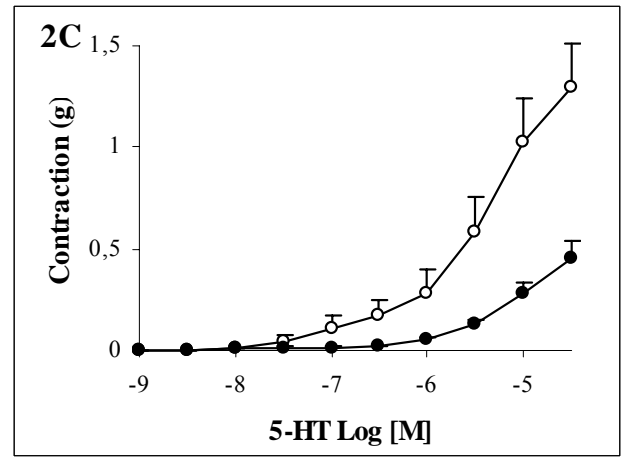

Figure 2: Concentration-response curves to 5-HT in rat aorta. Curves were obtained in the absence $(O)$ and presence of glibenclamide $(\bullet) 1 \mu \mathrm{M}(\mathbf{A}), 3 \mu \mathrm{M}$ (B) and $10 \mu \mathrm{M}(\mathbf{C})$. Values are mean \pm S.E.M., $(\mathrm{n}=5), * \mathrm{p}<0.05$, Wilcoxon matched-pairs signed rank test

Effects of endothelial mediators on the inhibitory effect of glibenclamide- In experiments testing the possible roles of endothelium-derived vasoactive factors, aortic rings were first exposed to a combination L-NNA $(100 \mu \mathrm{M})$ and indomethacin $(10 \mu \mathrm{M})$ for $30 \mathrm{~min}$ before they were contracted with $\mathrm{PGF}_{2 \alpha}$ or 5-HT cumulatively in the absence or presence of glibenclamide $(10 \mu \mathrm{M})$.

The results shown in Figure 4 and 5, indicates that the inhibitory influence of glibenclamide $(10 \mu \mathrm{M})$ on $\mathrm{PGF}_{2 \alpha^{-}}$and 5-HT-induced contractions were attenuated upon pretreatment with a combination of L-NNA and indomethacin. The inhibitory influence of glibenclamide on $\mathrm{PGF}_{2 \alpha^{-}}$ induced contractions was decreased from $86 \pm 2 \%$ (without L-NNA and indomethacin) to $46 \pm 10 \%$ (with L-NNA and indomethacin) and the inhibitory influence of glibenclamide on 5-HT-induced contractions was decreased from $65 \pm 5 \%$ to $50 \pm 5 \%$ upon pretreatment with a combination of LNNA and indomethacin. 

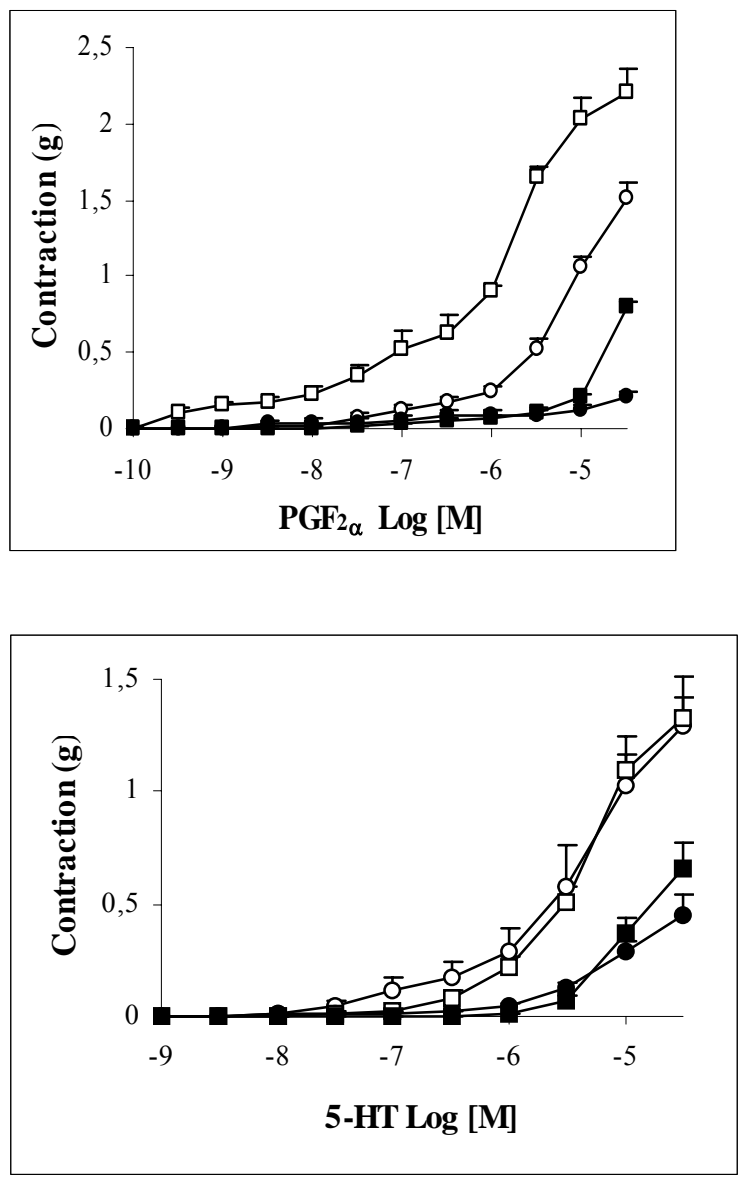

Figure 3: Concentration-response curves for the contraction induced by $\mathrm{PGF}_{2 \alpha}$ in the endothelium-intact and endothelium-denuded rat aorta. Curves were obtained in the absence $(\circ, \mathrm{n}=6)$ or presence of glibenclamide $(10 \mu \mathrm{M})(\bullet, \mathrm{n}=6)$ in the endothelium-intact arteries and in the absence $(\square, n=3)$ or presence of glibenclamide $(10 \mu \mathrm{M})(\square, \mathrm{n}=3)$ in the endothelium-denuded arteries. Values are mean \pm SEM. $+p<0.05$, Mann-Whitney Utest, between endothelium-intact and endothelium-denuded groups.

Figure 5: The concentration response curves for 5-HT in the endothelium-intact rat aorta. Curves were obtained in the absence $(\circ, \mathrm{n}=5)$ and presence of L-NNA plus indomethacin ( $\square$, $\mathrm{n}=5$ ) without glibenclamide or in the absence $(\bullet, n=5)$ and presence of L-NNA plus indomethacin $(\mathbf{\square}, \mathrm{n}=5)$ with glibenclamide (10 $\mu \mathrm{M})$. Values are mean \pm SEM. ${ }^{*} p<0.05$, Wilcoxon matched-pairs signed rank test, between glibenclamide treated and untreated arteries in the L-NNA plus indomethacin pretreatment group. $+\mathrm{p}<0.05$, Mann-Whitney U-test, between L-NNA plus indomethacin treated and untreated arteries in the glibenclamide treatment group.

The results of present study provide evidence that glibenclamide is a potent inhibitor of $\mathrm{PGF}_{2 \alpha}$-induced contraction in rat aorta. In 1990, an additional action of glibenclamide to competitively antagonise contractions to the thromboxane $\mathrm{A}_{2}$ mimetic, U46619, in canine isolated coronary arteries was discovered (5). Several studies have demostrated an ability of glibenclamide and other sulfonylureas to antagonise responses to U46619 and other prostanoids in vessels from the rabbit $(6)$, rat $(8,9,11)$, pig $(12)$, cow $(6,11)$ and humans (13) However, the ability of sulfonylureas to block prostanoid-induced contractions can not be generalized. Glibenclamide did not inhibit $\mathrm{PGF}_{2 \alpha^{-}}$and U46619-induced contractions in aorta and carotid arteries from guinea pigs and in human subcutaneous arteries (11). The reason for the heterogeneous influence of glibenclamide on prostanoid-induced contractions is unclear. It might be related to interspecies differences.

In order to find out the possible mechanism responsible for the inhibitory influence of glibenclamide on $\mathrm{PGF}_{2 \alpha}$-induced contraction, we also investigated whether this effect was specific 
for $\mathrm{PGF}_{2 \alpha}$. Therefore, in the present study we investigated the effect of glibenclamide on contractions induced by non-prostanoid vasoconstrictors, 5-HT and phenylephrine. Glibenclamide was found to concentration dependently inhibit the contractile response to 5-HT but phenylephrineinduced contractions were not altered by glibenclamide $(10 \mu \mathrm{M})$. Delaey and Van de Voorde (9) reported that glibenclamide has no or only limited influence on the contractions induced by 5-HT, phenylephrine, endothelin-1, noradrenaline and potassium $120 \mathrm{mM}$ in rat aorta. However, glibenclamide was reported to inhibit contractile responses of some vascular tissues to a number of constrictors, such as phenylephrine, endothelin- 1 , and $\mathrm{KCl}(13,14,15)$. Our results suggest that the inhibitory effect of glibenclamide was not specific for $\mathrm{PGF}_{2 \alpha}$ and glibenclamide at high concentrations may be a general smooth muscle relaxant. It is apparent that the observed inhibitory effect of glibenclamide on smooth muscle contractility is a property additional to its pharmacological action as a selective blocker of $\mathrm{K}_{\mathrm{ATP}}$ channels.

In a further series of experiments, we investigated whether the endothelium is involved in the inhibitory effect of glibenclamide on contractions induced by $\mathrm{PGF}_{2 \alpha}$ and 5-HT. Our results showed that the inhibitory effects of glibenclamide were attenuated by endothelial denudation of aortic rings. Pretreatment of endothelium-intact tissues with L-NNA and indomethacin, which are inhibitors of endothelium-derived relaxing factors, nitric oxide and prostacyclin, attenuated the influence of glibenclamide. This finding suggests that glibenclamide may act on the endothelium to release nitric oxide and prostacyclin which primarily accounts for an endothelium-dependent relaxation. Nitric oxide released from the endothelium has been shown to diffuse into the underlying vascular smooth muscle and to stimulate cGMP accumulation which mediates the nitric oxide-dependent relaxation (16). Chan et al. (14) previously demonstrated that exposure of endothelium-intact rat aortic rings to glibenclamide raised the tissue content of cGMP by approximately two-fold and this rise was abolished in the presence of the nitric oxide synthase inhibitor, L-NNA, or in the endothelium-denuded rings. These results support a significant role of endothelium in the inhibitory effect of glibenclamide in rat aorta. Our results also showed that the effect of glibenclamide appears to be partially associated with the presence of endothelium as deendothelisation attenuates the inhibitory effect by $22 \%$. Our result contrasts with the earlier observation with canine middle cerebral arteries in which glibenclamide-induced relaxation was unaltered in the endothelium-removed tissues (8). This discrepancy might be caused by the use of arteries from two different species.

Our data show that the inhibitory effect of glibenclamide on the contractile responses of $\mathrm{PGF}_{2 \alpha}$ was greater in endothelium-denuded arteries than in endothelium-intact arteries pretreated 
with L-NNA and indomethacin. As the inhibitory effect of glibenclamide was not completely abolished by interventions to endothelium, the residual endothelium-independent effect observed with glibenclamide might result from its direct relaxant effect on aortic smooth muscle.

In summary, although there are increasing numbers of studies in this area of research, conflicting data still exists regarding the mechanism of the action of glibenclamide as an inhibitor of contractile agonists. This results mainly from the usage of different arteries from a number of different species of experimental subjects. To the best of our knowledge, this is the first study to demonstrate the effects of glibenclamide on various constrictors and dependence of these effects on endothelium or endothelium derived factors together on rat aorta. Present results demonstrate that glibenclamide not only inhibits contractions of $\mathrm{PGF}_{2 \alpha}$ but also inhibits 5-HT contractions in a concentration dependent manner. These data show that inhibitory effect of glibenclamide is not selective for $\mathrm{PGF}_{2 \alpha}$, even though Pfister et al. (6) showed the blockage of vascular thromboxane receptors. Furthermore, denudation of endothelium significantly reduced inhibitory effect of glibenclamide, but inhibitory effect was not completely abolished. In other words, glibenclamide induced both endothelium-dependent and -independent inhibitory effect. It is possible that glibenclamide could act through multiple sites in either endothelium or the underlying arterial smooth muscle and thus serve as a non-selective muscle relaxant at high concentration. The exact mechanism for the inhibition remains unclear.

\section{ACKNOWLEDGEMENTS}

This work was supported by a grant from the Ege University Scientific Research Fund (2000/ECZ/023).

\section{REFERENCES}

1. Ashcroft, F.M. and Gribble, F.M. "Correlating structure and function in ATP-sensitive $\mathrm{K}^{+}$ channels", Trends Neurosci, 21, 288-294, (1998).

2. Ashcroft, F.M. and Gribble, F.M. "Tissue-spesific effects of sulfonylureas Lessons from studies of cloned $\mathrm{K}_{\mathrm{ATP}}$ channels", J Diabetes Complicat, 14, 192-196, (2000).

3. Quayle, J.M., Nelson, M.T. and Standen, N.B. "ATP-Sensitive and inwardly Rectifying potassium channels in smooth muscle”, Physiol Rev, 77, 1165-1232, (1997).

4. Quast, U. and Cook, N.S. "In vitro and in vivo comparison of two $\mathrm{K}^{+}$channel openers, diazoxide and cromakalim, and their inhibition by glibenclamide", J Pharmacol Exp Ther, 250, 261-271, (1989).

5. Cocks, T.M., King, S.J. and Angus, J.A. "Glibenclamide is a competitive antagonist of the 
thromboxane $\mathrm{A}_{2}$ receptor in dog coronary artery in vitro", Brit J Pharmacol, 100, 375-378, (1990).

6. Pfister, S.L., Pratt, P.E., Kurian, J. and Campbell, W.B. "Glibenclamide inhibits thromboxane-mediated vasoconstrction by thromboxane receptor blockade", Vasc Pharmacol, 40, 285-292, (2004).

7. Nielsen-Kudsk, J.E. and Thirstrup, S. “Antidiabetic sulfonylureas relax isolated rabbit coronary arteries", Eur J Pharmacol, 209, 273-275, (1991).

8. Zhang, H., Stockbridge, N., Weir, B., Krueger, C. and Cook, D. “Glibenclamide relaxes vascular smooth muscle constriction produced by prostaglandin $\mathrm{F}_{2 \alpha}$ " Eur J Pharmacol, 195, 27-35, (1991).

9. Delaey, C. and Van de Voorde, J. "Prostanoid-induced contractions are blocked by sulfonylureas", Eur J Pharmacol, 280, 179-184, (1995).

10. Zhang, H., and Cook, D., "Antagonism of eicosanoid-induced contraction of rat aorta by sulphonylureas", Pharmacology, 49, 173-183, (1994).

11. Delaey, C. and Van de Voorde, J. "Heterogeneity of the inhibitor influence of sulfonylureas on prostanoid-induced smooth muscle contraction", Eur J Pharmacol, 325, 41-46, (1997).

12. McPherson, G.A., Choi, R.T., Kong, D.C.M. and Iskander, M.N. "The thromboxane $A_{2}$ and $\mathrm{K}_{\mathrm{ATP}}$ channel antagonist actions of a series of sulphonylurea derivatives in the pig coronary artery", Eur J Pharmacol, 324, 193-200, (1997).

13. Stanke, F., Cracowski, J.-L., Chavanon, O., Magne, J.-L., Blin, D., Bessard, G. and Devillier, P. "Glibenclamide inhibits tromboxane $\mathrm{A}_{2}$-induced contraction in human internel mammary artery and saphenous vein”, Eur J Pharmacol, 341, 65-71, (1998).

14. Chan, W.-K., Yao, X., Ko, W.-H. and Huang, Y. "Nitric oxide mediated endotheliumdependent relaxation induced by glibenclamide in rat isolated aorta", Cardiovasc Res, 46, 180-187, (2000).

15. Huang, Y. and Chan, N.W.K. "Involvement of endothelium in relaxant action of gibenclamide on the rat mesenteric artery”, Eur J Pharmacol, 343, 27-33, (1998).

16. Ignarro, L.J., Burke, T.M., Wood, K.S., Wolin, M.S. and Kadowitz, P.J. “Association between cyclic GMP accumulation and acethylcholine-elicited relaxation of bovine intrapulmonary artery", J Pharmacol Exp Ther, 228, 682-690, (1984).

Received: 24.06.2005

Accepted: 21.07.2005 